\title{
Marketability and Financial Performance of Suyac Mangrove Eco-Park
}

\author{
Nince L. Mate ${ }^{1}$ and Kristin Iris G. Estores ${ }^{2}$ \\ ${ }^{1}$ Northern Negros State College of Science and Technology, Sagay City, Philippines \\ ${ }^{2}$ University of Negros Occidental-Recoletos, Bacolod City, Philippines
}

\begin{abstract}
Article history
Submitted: 25 October 2020

Revised: 5 November 2020

Accepted: 10 November 2020

\section{Keywords}

Business Administration

Hospitality and Tourism

Marketability

Financial Performance

Descriptive

Suyac Mangrove Eco-Park

Negros Occidental
\end{abstract}

Introduction. Ecotourism has shown significant fast-paced growth and is recently getting tremendous attention in the world. However there are many challenges in product development and marketing. Suyac Mangrove Eco-Park needs the right marketing research for its community-based ecotourism development for people's welfare, especially the community and the tourists. Hence, the study assesses the level of marketability in terms of 7P's marketing mix and financial performance of Suyac Mangrove Eco-Park. Likewise, this study sought if a significant difference exists in the level of marketability when respondents are grouped according to designation.

Methods. The study used a descriptive-comparative research design The data were gathered using a validated and reliability-tested researcher-made survey questionnaire which were accomplished by tourism staff, residents, and tourists as respondents. The secondary data were used to analyze the financial performance. Mean, standard deviation, frequency count, percentage distribution, and Analysis of Variance (ANOVA) were used for descriptive and comparative. Meanwhile, the profitability ratios using vertical and horizontal analysis were utilized for the financial performance.

Results. The findings of the study revealed that provisions or conditions of Suyac Mangrove EcoPark in terms of 7P's marketing mix (product, price, place, people, promotion, process, and physical evidence) are implemented and functioning well. On the other hand, Promotion ranked lowest. There is no significant difference in the marketability in terms of product, place, price, people, promotion, and process when the assessors are grouped according to the designation. However, there is a significant difference in the level of marketability in terms of physical evidence when the assessors are grouped according to the designation. Post hoc test revealed that the city tourism authority rated this area significantly higher than the residents did. In terms of the financial performance of Suyac Mangrove Eco-Park for the year 2015-2018, the analysis revealed that although the sales increased yearly, the operating expenses of the Eco-Park also followed. The results of the study yielded the formulation of a three-year marketing plan that could help guide in identifying areas for development and in formulating market programs for the future improvement of the ecotourism destination.

Conclusion. Suyac Mangrove Eco-Park, as an ecotourism destination, has its tourism potential as an island with pristine mangrove resources, which are its main iconic product and inherent attractiveness. In terms of promotion, most marketing tools need to be planned appropriately, utilized, implemented, and evaluated effectively. Suyac Mangrove Eco-Park Management may strengthen the primary activities and local resources of the ecotourism destination. Furthermore, the management may come up with convenient and well-planned accounting processes and procedures for proper documentation of their financial performance. All components of $7 \mathrm{P}^{\prime} \mathrm{s}$ are necessary to formulate a marketing plan for Suyac Mangrove Eco-Park to improve tourists' awareness and provide better services to tourists and exceed their expectations. The formulation of a three-year marketing plan will help identify areas for development, formulating market programs, and facilitating the improvement of the ecotourism destination. 
Practical Value of the Paper. In Negros Occidental, no local market research studies or published outputs of an ecotourism destination were done concerning its marketability and economic performance. The study will offer novelty and be a significant contributor to the field to address the research gap.

\section{References}

Arif, T., Jannat, K., \& Anwar, S. (2016). Financial statement and competitive analysis: a study on the tourism \& hospitality industry in Bangladesh. International Journal of Financial Research,7(4).

Binter, U., Ferhan, M., \& Neves, J. (2016). Marketing mix and tourism destination image: the study of destination bled, Slovenia. Organizacija, 49(4),

Cirikovic, E. (2014). Marketing mix in tourism. Academic Journal of Interdisciplinary Studies,3(2).

Diaz, M., \& Rodriguez, T. (2016). Determining the sustainability factors and performance of a tourism destination from the stakeholder's perspective. Sustainability 8, 951.

doi: 103390/su8090951.

Dimitri', M., Zikovic, I., \& Blecich, A. (2019). Profitability determinants of hotel companies in selected Mediterranean countries.Economic Research- Ekomska Istrazivanja, 32(1).1977-1993.

Iacovou, C. (2016). An analysis of social media marketing and strategies and best practices of hospitality and tourism organizations. Published by Pro Quest LLC. (2016).

Magatef, S. (2015). The impact of tourism marketing mix elements on the satisfaction of inbound tourists to Jordan. International Journal of Business and Social Science, 6(7).

Mohammed, E (2014). Assessment of tourism marketing strategy in tourism destination: A case study in Bali Mountain National Park- Bale Zone, Thesis. Mekelle:MU.doi: https://opendocs.ids.ac.uk/opendocs/ handle/20.500.12413/4989.

Nouri1, B., \& Soltani, M. (2015). Evaluating the effect of tourism marketing mix on buying holiday homes in Cyprus International Journal of Business Administration, 6(5).

Saif, N. (2015). How does marketing strategy influence firm performance? Implementation of marketing strategy for firm success. International Journal of Innovation and Economic Development,1(3). 7-15.

\section{Correspondence:}

Nince L. Mate [nlmate07@gmail.com]

https://orcid.org/0000-0002-2698-5763 